\title{
Pisolithus sp. TOLERANCE TO GLYPHOSATE AND ISOXAFLUTOLE In Vitro ${ }^{1}$
}

\author{
Mayara Cristina Silva Fernandes², Lidiomar Soares da Costa ${ }^{3}$, Paulo Henrique Grazziotti ${ }^{4}$, Danielle Cristina
} Fonseca Santos Grazziotti ${ }^{5}$, José Barbosa dos Santos ${ }^{6}$ e Márcio José Rossi ${ }^{7}$

\begin{abstract}
The ectomycorrhizal fungi have different tolerance to herbicides and may promote the survival and growth of the eucalypts tree. This study aimed to evaluate the tolerance of Pisolithus sp. isolates to glyphosate and isoxaflutole. The isolates evaluated were D3, D16, D17, Pt24 and UFVJM04. Glyphosate concentrations were: 0, 32, 63, 127 and $254 \mathrm{mg} \mathrm{L}^{-1}$ in liquid medium; 0, 32, 63, 127, 254, 507 and $1014 \mathrm{mg} \mathrm{L}^{-1}$ in solid medium. For isoxaflutole, the concentrations were 0, 295, 589, 1178 and $2355 \mathrm{mg} \mathrm{L}^{-1}$ for both media. Assays were independent for each herbicide and culture medium. The tolerance of isolates depended on the herbicide and its concentration in each type of culture medium. Pt24 was the most tolerant to glyphosate and the UFVJM04 to isoxaflutole. Glyphosate was more toxic to isolates of Pisolithus than isoxaflutole.
\end{abstract}

Keywords: Herbicide: Ectomycorrhiza: Eucalyptus.

TOLERÂNCIA DE Pisolithus sp. A GLYPHOSATE E ISOXAFLUTOLE In Vitro

RESUMO - Os fungos ectomicorrízicos possuem tolerância diferenciada aos herbicidas e podem promover a sobrevivência e crescimento das plantas de eucalipto. O objetivo deste trabalho foi avaliar a tolerância de isolados do fungo ectomicorrízico Pisolithus sp. aos herbicidas glyphosate e isoxaflutole. Os isolados avaliados foram D3, D16, D17, Pt24 e UFVJM04 e as concentrações de glyphosate no meio líquido, de 0, 32, 63, 127 e $254 \mathrm{mg} \mathrm{L}^{-1}$, enquanto no meio sólido, de 0, 32, 63, 127, 254, 507 e $1.014 \mathrm{mg} \mathrm{L}^{-1}$. Para o isoxaflutole nos dois meios de cultura, as concentrações foram de: 0, 295, 589, 1.178 e $2.355 \mathrm{mg} \mathrm{L}^{-1}$. Os ensaios foram independentes para cada herbicida e tipo de meio de cultura. A tolerância dos isolados foi dependente do herbicida e da sua concentração em cada meio. O Pt24 foi o mais tolerante ao glyphosate e o UFVJM04, a isoxaflutole. O glyphosate foi mais tóxico aos isolados de Pisolithus sp. do que o isoxaflutole.

Palavras-chave: Herbicida; Ectomicorriza; Eucalyptus.

\footnotetext{
${ }^{1}$ Recebido em 08.08.2013 aceito para publicação em 29.04.2014.

${ }^{2}$ Graduanda em Engenharia Florestal, Universidade Federal dos Vales do Jequitinhonha e Mucuri, Diamantina, MG, Brasil. E-mail: <mayaracsf18@gmail.com>.

${ }^{3}$ Programa em Pós-gradaução em Produção Vegetal, Universidade Federal dos Vales do Jequitinhonha e Mucuri, Diamantina, MG, Brasil. Email: <lidiomar.ef@bol.com.br>.

${ }^{4}$ Departamento de Engenharia Florestal, Universidade Federal dos Vales do Jequitinhonha e Mucuri, Diamantina, MG, Brasil. E-mail: <grazziot@yahoo.com.br>.

${ }^{5}$ Instituto de Desenvolvimento do Norte e Nordeste, Minas Gerais, Brasil. E-mail: <daniagronomia@yahoo.com.br>.

${ }^{6}$ Departamento de Agronomia, Universidade Federal dos Vales do Jequitinhonha e Mucuri, Diamantina, MG, Brasil. E-mail: <jbarbosasantos@yahoo.com.br>.

${ }^{7}$ Departamento de Microbiologia, Imunologia e Parasitologia, Universidade Federal de Santa Catarina, SC, Brasil. E-mail: <marcio@enq.ufsc.br>.
} 


\section{INTRODUCTION}

Sustainability has been an increasing concept in bioenergy production, and ectomycorrhizae can contribute on this, helping in eucalypts establishment in nutrientpoor or degraded soils. They increase volume of exploited soil by roots improving water and nutrients absorption, in special those with low mobility, as phosphorus (MARX; CORDELL, 1989). In addition to this these benefits, ectomycorrhizae can provide great resistance to high temperatures and extreme $\mathrm{pH}$ (MARX; CORDELL, 1989) and increase root longevity (ALLEN, 1991), as well as dry matter production stimulation (SOUZA et al., 2004) and provide greater tolerance to soil toxicity conditions and pathogens (ALLEN, 1991; GRAZZIOTTI et al., 2003).

Eucalypts is the forest species most grown in Brazil and, due to increasing demand for wood and limitation of new areas, there is a need to enhance seedling survival and growth in field conditions and, with this, boosting yield of production areas. Thus, ectomycorrhizal fungi (EMF) inoculation in eucalypts seedlings might enhance plant productivity. Among EMF used in commercial plantings in Southeastern Brazil, Pisolithus is one with the most occurrence, and several researches have evinced isolate capacity of the genus to promote growth of inoculated seedlings (ALVES et al., 2001; SILVA et al., 2007; SOUZA et al., 2008).

Ectomycorrhizal associations depend on interaction with soil, environment, and host plants and can be influenced by adopted crop management (CAMPOS et al., 2011). In order to use EMF, it is necessary to know about herbicide effect on fungi, since in major planted forests, these products are used to prevent damages by weeds. Invasive species control is necessary once weed impose difficulties in seedling establishment in field, because they harm seedling development and growth by allelopathic effects (TOLEDO et al., 2003), and water, nutrient and light competition. Moreover, weed can increase fire risks and hinder other forestry practices (TUFFI SANTOS et al., 2006).

Herbicide use by forest sector companies has been practiced increasingly and might have, as an indirect consequence, inhibition of ectomycorrhizal formation (ILOBA, 1978; CULDLIN et al., 1983; TRAPPE et al., 1984). Nevertheless, some studies have pointed out that herbicides also may not influence (WARDLE; PARKINSON, 1991) or, even though, stimulate (ROSLYCKY, 1982) EMF growth. This EMF response to herbicides depend on species, herbicide type and dosage (TRAPPE et al., 1984; MOORMAN, 1989). Pisolithus tinctorius had its growth in solid medium reduced from $1 \mathrm{mg} \mathrm{L}^{-1}$ of triclopyr, glyphosate, hexazinone and 2,4-D herbicides, being completely inhibited in $5,000 \mathrm{mg} \mathrm{L}^{-1}$ of same herbicides. Yet Hebeloma longicaudum growth was inhibited in $100 \%$, at 1,000 mg L ${ }^{-1}$ of triclopyr and 2,4-D concentrations, and other herbicides have inhibited growth in 55\% at $100 \mathrm{mg}$ $\mathrm{L}^{-1}$ concentration, while Cenococcum geophilum growth was stimulated in 53\% up to $10 \mathrm{mg} \mathrm{L}^{-1}$ dose for triclopyr and hexazinone (ESTOK et al., 1989). A P. tinctorius isolated had growth in solid culture medium reduced by $59 \%$ at $50 \mathrm{mg} \mathrm{L}^{-1}$ concentration of glyphosate and completely inhibited in same concentration for oxyfluorfen (PAULA Jr. et al., 1995). However, another P. tinctorius isolate did not have growth, in liquid medium, impaired for glyphosate concentrations up to $10 \mathrm{mg} \mathrm{L}^{-1}$ (LAKE et al., 1981). Otherwise, same specie growth was reduced in solid medium with $1 \mathrm{mg} \mathrm{L}^{-1}$ hexazinone (KELLEY; SOUTH, 1980).

Current researches demonstrate that Pisolithus sp. isolates have great difference in ability to colonize and promote growth of eucalypts seedlings in nursery gardens (FONSECA, 2013). Nonetheless, searching for terms such as herbicides, ectomycorrhizae, "herbicida”, “ectomicorriza” through Scopus, Scielo and Cab direct bibliographical databases, we have not found any research that had evaluated tolerance of different isolates of a same EMF. Thereby, we aimed in the current research to evaluate Pisolithus sp. isolate tolerance to glyphosate and isoxaflutole.

\section{MATERIALAND METHODS}

Growth of fungal isolates D3, D16, D17 and UFVJM04 of Pisolithus sp., were gotten from Eucalyptus spp. plantations in the Alto Vale do Jequitinhonha, and the Pt 24 isolate of Pisolithus sp., was gotten from Pinus sp. plantations in Santa Catarina. These isolates were evaluated in liquid and solid Melin-Norkransmodified medium (MNM) (MARX, 1969) added of increasing concentrations of glyphosate $\left(\right.$ Scout $\left.^{\circledR}\right)$ and isoxaflutole (Fordor ${ }^{\circledR}$ ) herbicides. Pt 24 Pisolithus sp. isolate belongs to collection of the Laboratory of Ectomycorrhizae from Microbiology and Parasitology Department in Federal University of Santa Catarina, and other isolates came from the Laboratory of Soil Microbiology collection in Federal University of Vales do Jequitinhonha e Mucuri. 
Scout ${ }^{\circledR}$ is a systemic and non-selective herbicide of replaced glycine chemical group, its active principle is glyphosate ammonium salt, and is considered medium toxic (BRASIL, MAPA, 2013). Fordor ${ }^{\circledR}$ is a contact selective herbicide of isoxazol chemical group, its active principle is isoxaflutole that is considered extremely toxic (BRASIL, MAPA, 2013). Both formulas are widely used in eucalypts crop.

For glyphosate, concentrations were established for the two culture mediums, based on preliminary test and at $\mathrm{LD}_{50}$ for trout that is $80 \mathrm{mg} \mathrm{L}^{-1}$, being this the most sensitive test-organism when compared with birds and insects (RODRIGUES; ALMEIDA, 2011). Herbicides concentrations were obtained in a laminar flow chamber from herbicide stock-solution, which were prepared with distilled and sterilized water. Isoxaflutole concentrations were set, also for solid and liquid mediums, based on recommended dosage for eucalypts that is $200 \mathrm{~g} \mathrm{ha}^{-1}$, estimated for the Petri dish area (100 mm diameter).

From isolate culture grown by 29 days at $25^{\circ} \mathrm{C}$ in MNM solid culture medium, 5-mm diameter discs were removed from borders of each isolate colonies. After that, discs were transferred into Petri dishes with same medium and incubated for more three days under same conditions. Then, allowing retrieval of damaged mycelium during subculturing, confirming viability and ensuring contamination absence. This initial procedure was carried out into all performed assays.

\subsection{Assay in liquid culture medium}

Fifty milliliters of culture medium were placed into 125-mL Erlenmeyer flasks and subsequently sterilized by $15 \mathrm{~min}$ at $121^{\circ} \mathrm{C}$. After culture medium cooling, in laminar flow hood, stock-solution was added into the medium to produce final concentrations of $0,32,63$, 127 and $254 \mathrm{mg} \mathrm{L}^{-1}$ of glyphosate and 0, 295, 589, 1178 and $2355 \mathrm{mg} \mathrm{L}^{-1}$ of isoxaflutole. Then, 10 disks of 5 mm diameter from edges of isolate colonies, previously grown per three days, were added into flasks and incubated at $25^{\circ} \mathrm{C}$.

Flasks were softly stirred per 3 seconds every day, and, by the end of 30 days, mycelium was collected a sieve with aperture diameter of $0.053 \mathrm{~mm}$, washed with distilled water and dried at $60^{\circ} \mathrm{C}$ until constant weight, for mycelium dry mass determination (MDM) and calculation of tolerance index (TI). For this calculation, dry mass production of medium containing herbicide are multiplied by 100 , and divided by dry mass production without herbicide. So, this variable was used for isolate comparison since they have a differentiated growth.

\subsection{Assay in solid culture medium}

Culture medium was sterilized and, after being cooled up to $45^{\circ} \mathrm{C}$ in water-bath, received aliquots of stocksolution to produce the following concentrations: 0 , 32, 63, 127, 254, 507 and $1014 \mathrm{mg} \mathrm{L}^{-1}$ of glyphosate and $0,295,589,1178$ and $2355 \mathrm{mg} \mathrm{L}^{-1}$ of isoxaflutole. Immediately after that, $20 \mathrm{~mL}$ of the medium were poured into Petri dishes of $100 \mathrm{~mm}$ diameter. After medium solidification, a disk, containing a previously grown mycelium per three days, was placed at central part of each Petri dish with mycelium facing upwards and incubated at $25^{\circ} \mathrm{C}$ per 30 days. At the end of this period, radial growth of isolate colonies was evaluated by twocolony diameter average measured at two different directions. As isolates present different radial growth, we also calculated TI, for tolerance comparison among isolates regarding the herbicide, as described by test in liquid medium.

\subsection{Design and statistical analyses}

Herbicides and culture medium types were analyzed in independent assays using a totally randomized design with four replications. For glyphosate assays in liquid medium and isoxaflutole in the two medium types (liquid and solid), treatments were organized in a $5 \times 5$ factorial scheme, performed by the five EMF isolates and the five herbicide concentrations. In relation of glyphosate test in solid medium, treatments were established by a $5 \times 7$ factorial scheme with same isolates and seven herbicide concentrations. Statistical analysis for TI data was performed by variance analysis and, when interaction was significant, we tried to establish regressions.

\section{RESULTS}

\subsection{Tolerance of isolates in liquid medium}

In descending order, Pisolithus sp. isolates that have presented greater growth in liquid medium without glyphosate and isoxaflutole addition, were: D16 = $232.9 \mathrm{mg}$; D3 = 203.4 mg; D17 = 177.8 mg; UFVJM04 = 149.6 mg; and Pt24 = $118.4 \mathrm{mg}$. Pisolithus sp. isolates differed ( $\mathrm{P}>0.05)$ with respect to tolerance to glyphosate and isoxaflutole concentrations (Table 1).

Revista Árvore, Viçosa-MG, v.38, n.3, p.461-468, 2014 
Table 1 - Mean square error and variation coefficient (VC) of tolerance index (TI) of fungal isolates D3, D16, D17, and PT24 UFVJM04 of the Pisolithus sp. grown on liquid medium with herbicides.

Tabela 1 - Quadrado médio do resíduo e coeficiente de variação (VC) do índice de tolerância (TI) dos isolados fúngicos D3, D16, D17, UFVJM04 e Pt24 de Pisolithus sp. crescidos em meio de cultura sólido com herbicidas.

\begin{tabular}{lcccc}
\hline \multicolumn{1}{c}{ Variáveis } & Fungo (F) & Concentração (C) & F x C & CV\% \\
\hline IT ao glyphosate & $6,849.7^{*}$ & $19,008.5^{*}$ & $1,197.9^{*}$ & 28.5 \\
IT ao isoxaflutole & $3,225.4^{*}$ & $2,712.7^{*}$ & $2,759.8^{*}$ & 42.6 \\
\hline
\end{tabular}

$*$ = significant at $5 \%$ by $\mathrm{F}$ test.

* = significativo a $5 \%$ pelo teste $F$

For glyphosate, all Pisolithus sp. isolates had TI reduced with increasing concentrations, despite no adjustment has been found for regression in majority of isolates, except D3. TI of this isolate showed a behavior explained by an squared root equation, reaching 50\% reduction at $33.4 \mathrm{mg} \mathrm{L}^{-1}$ concentration (Figure $1 \mathrm{a}$ ). In a concentration next to that, $32 \mathrm{mg} \mathrm{L}^{-1}$, isolate tolerance order was: Pt24 $=88.6 \%>$ D3 $=47.5 \%>$ UFVJM0 $4=$ $19.2 \%>\mathrm{D} 17=16.0 \%>\mathrm{D} 16=12.8 \%$, being the Pt24 TI at $63 \mathrm{mg} \mathrm{L}^{-1}$ concentration of $58.8 \%$, still bigger than the remaining ones. Pt24 and D3, besides presenting a greater TI than others at $32 \mathrm{mg} \mathrm{L}^{-1}$ concentration, both also presented great MDM production at this glyphosate dosage. Mycelium production at this glyphosate concentration was Pt24 = 104.9 mg; D3 = 96.6 mg; D6 = $29.8 \mathrm{mg}$; UFVJM04 = $28.7 \mathrm{mg}$; and D17 = $28.5 \mathrm{mg}$.

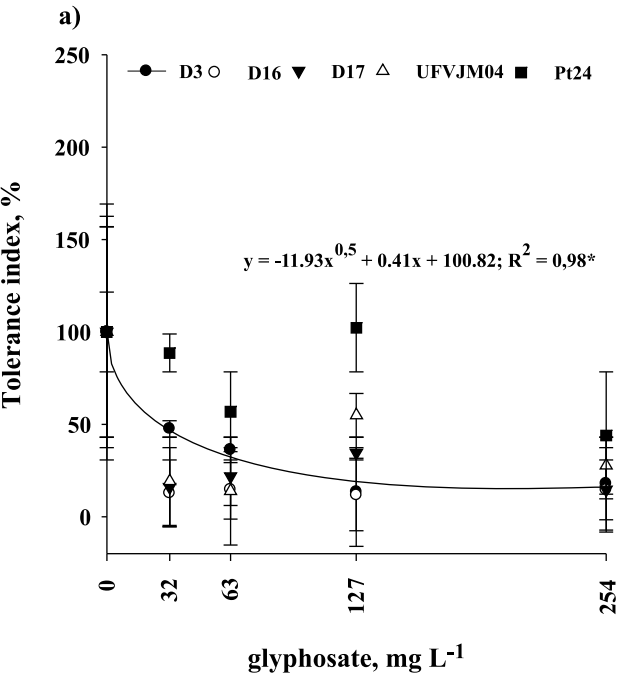

Isoxaflutole promoted a widely varied effect on mycelium production what is confirmed by high value of variation coefficient (Table 1; Figure 1b). D3 TI index presented linear reduction, coming to a maximum of $35 \%$ at a concentration of 2,36 $\mathrm{mg} \mathrm{L}^{-1}$ (Figure 1b). Even though, we did not find regression curve fit for the other isolates, at this concentration, tolerance order was UFVJM04 = 134.2\% > Pt24 = 95.2\% > D16 = 71.8\% $>\mathrm{D} 3=68.3 \%>\mathrm{D} 17=59.9 \%$.

\subsection{Tolerance of isolates in solid medium}

In descending order, Pisolithus sp. isolates that have presented greater growth in liquid medium without glyphosate and isoxaflutole addition, were: D3 = $74.5 \mathrm{~mm}$; UFVJM04 = $65.0 \mathrm{~mm}$; D16 = $61.3 \mathrm{~mm}$; $\mathrm{D} 17=47.1 \mathrm{~mm}$; and Pt24 $=40.3 \mathrm{~mm}$. Pisolithus sp.

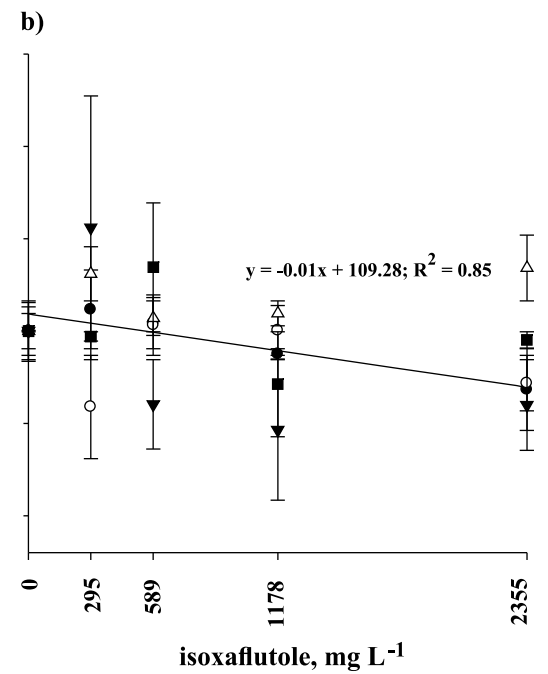

\footnotetext{
* = significant at $5 \%$ by $\mathrm{F}$ test.

* = significativo a $5 \%$ pelo teste $F$
}

Figure 1 - Tolerance index (TI) of isolates of the ectomycorrhizal fungus Pisolithus sp. grown on liquid culture medium MNM added glyphosate (a) or isoxaflutole (b).

Figura 1 - Índice de tolerância (TI) de isolados do fungo ectomicorrízico Pisolithus sp. crescidos em meio de cultura MNM líquido adicionado de glyphosate (a) ou isoxaflutole (b).

Revista Árvore, Viçosa-MG, v.38, n.3, p.461-468, 2014 
isolates have differed $(\mathrm{P}>0.05)$ regarding tolerance to glyphosate and were not influenced by isoxaflutole (Table 2).

Glyphosate promoted highly variable effect on colony diameter in solid culture medium (Figure 2a). The TI of D16 reduced linearly with increasing concentrations, reaching a maximum reduction of 50\% at $810.7 \mathrm{mg} \mathrm{L}^{-1}$ glyphosate concentration (Figure 2a). Despite, there is no adjustment found for regression of major isolates at concentration next to this, 1.014 $\mathrm{mg} \mathrm{L}^{-1}$ of glyphosate, tolerance order of isolates was: Pt24 = 115.5\% > UFVJM04 = 106.6\% > D17 = 104.8\% $>\mathrm{D} 3=82.9 \%>\mathrm{D} 16=41.6 \%$.

Isolates used in this current research had low tolerance to increasing concentrations of glyphosate, being still smaller than tolerance of $P$. tinctorius to the same herbicide, where fungus had mycelium dry mass reduced in 20\%, at a concentration of $250 \mathrm{mg}$ $\mathrm{L}^{-1}$ glyphosate in same liquid culture medium, grown per 30 days (PAULA JR. et al., 1995). Nonetheless, all studied isolates were more tolerant than Scleroderma aurantium was, which had dry mycelium production completely inhibited at $1 \mathrm{mg} \mathrm{L}^{-1}$ glyphosate (LAKE et al., 1981). Although these studies did not specify what commercial product was used, such results indicated importance of knowing EMF tolerance to various herbicides before use in Programs of Eucalypts Seedling Mycorrhization.

Isoxaflutole effect on MDM production have demonstrated variable tolerance of Pisolithus sp. studied isolates, since MDM increased for UFVJM04, and it was little influenced by Pt24 or reduced in D16, D3 and D17, confirming a differentiated behavior yet observed. Under bigger concentration of isoxaflutole, TI index of D3, despite being the second smallest, mycelium dry mass was of $153.5 \mathrm{mg}$, greater than that produced for UFVJM04, isolate with the biggest TI, in medium without herbicide (149.6 mg).
Isolate varied behaviors with regards to presence and herbicide type have demonstrated tolerance variation in accordance with these substances, where TI of Pisolithus sp. studied isolates increased for Pt24, had little influence by UFVJM04 and D17 isolates or reduced for D3 and D16, as observed under effect of isoxaflutole in liquid medium (Figure 1b). However, some isolate behaviors was dependent on used herbicide. In the highest concentration, TI of D3, despite being the second smallest, presented a growth in colony diameter of $56.5 \mathrm{~mm}$, which was greater than $46.4 \mathrm{~mm}$ of Pt24, that obtained the biggest TI. Thus, as seen in this isolate in liquid medium with addition of isoxaflutole, the great mycelium production can also allow glyphosate use in areas where inoculated seedlings with this isolate were planted.

For isoxaflutole, Pisolithus sp. isolates demonstrate tolerance in studied concentrations, presenting colony diameter similar to control. This result differs from the observed, also in solid medium, for triclopyr, glyphosate, hexazinone and 2,4-D herbicides, that at concentrations higher than $100 \mathrm{mg} \mathrm{L}^{-1}$ inhibited C. geophilum, $H$. longicaudum and $P$. tinctorius growth (ESTOK et al., 1989). As large-scale use of isoxaflutole in eucalypts for direct application in plants, results are interesting, since admit its possible use at lower effect on tested isolates, making them better options of inoculation in plantations, which may use herbicide for weed control.

Isolates of the ectomycorrhizal fungus Pisolithus sp. presented differentiated tolerance to studied herbicides, and this tolerance varied according to herbicide type, concentrations and culture medium (liquid and solid). For glyphosate, isolates were sensitive in liquid medium (Figure 1a) and little influenced in solid medium (Figure 2a). Yet for isoxaflutole, isolates had little influence in liquid medium and were tolerant in the solid one. These results disagree with the classification of glyphosate as middle toxicity and

Table 2 - Mean square error and variation coefficient (VC) of tolerance index (TI) of fungal isolates D3, D16, D17, and PT24 UFVJM04 of the Pisolithus sp. grown on solid medium with herbicides.

Tabela 2 - Quadrado médio do resíduo e coeficiente de variação (VC) do índice de tolerância (TI) dos isolados fúngicos D3, D16, D17, UFVJM04 e Pt24 de Pisolithus sp. crescidos em meio de cultura sólido com herbicidas.

\begin{tabular}{lccc}
\hline Variáveis & Fungo (F) & Concentração (C) & F x C \\
\hline IT ao glyphosate & $4,242.62^{*}$ & $601.10^{\text {n.s. }}$ & $1,360.36^{*}$ \\
IT ao isoxaflutole & $94.47^{\text {n.s. }}$ & $44.29^{\text {n.s. }}$ & 19.05 \\
\hline
\end{tabular}

n.s. = not significant at $5 \%$ by $\mathrm{F}$ test; $*=$ significant at $5 \%$ by $\mathrm{F}$ test.

n.s. = não significativo a $5 \%$ pelo teste $F ; *$ significativo a $5 \%$ pelo teste $F$.

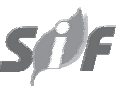

Revista Árvore, Viçosa-MG, v.38, n.3, p.461-468, 2014 


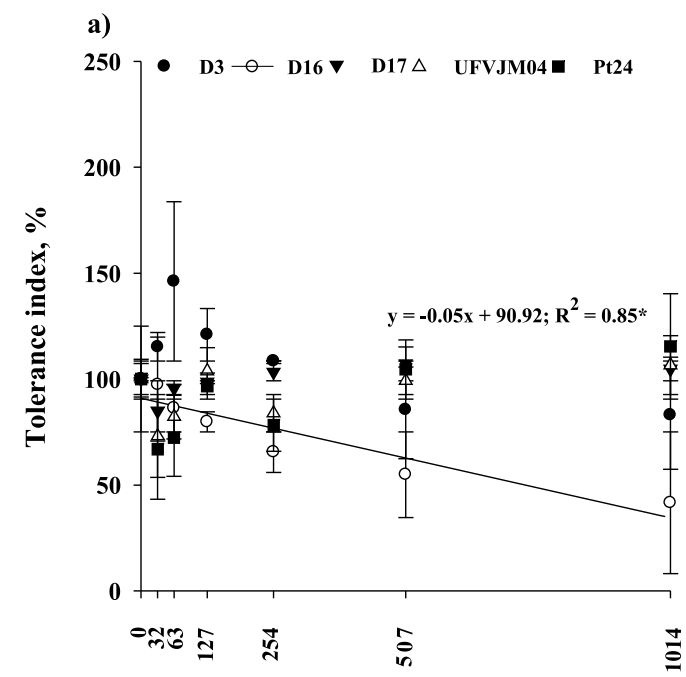

glyphosate, $\mathrm{mg} \mathrm{L}^{-1}$ b)

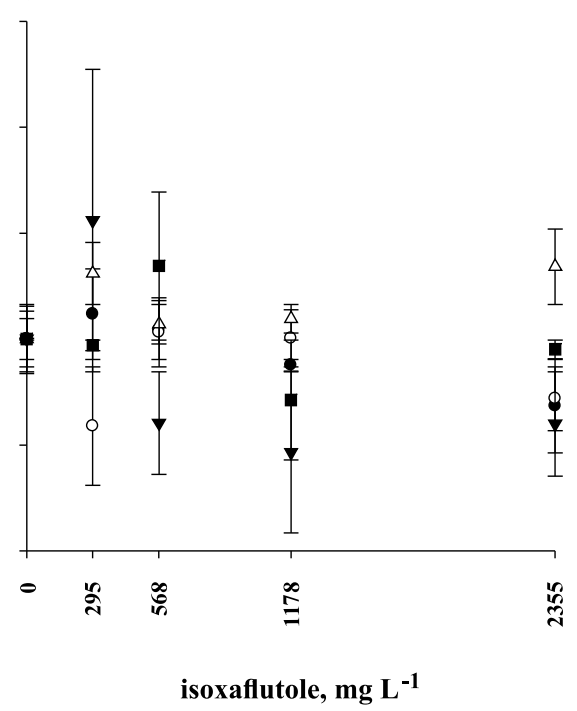

$*=$ significant at $5 \%$ by $\mathrm{F}$ test.

* = significativo a $5 \%$ pelo teste $F$

Figure 2 - Tolerance index (IT) of isolates of the ectomycorrhizal fungus Pisolithus sp. grown on solid culture medium MNM added glyphosate (a) or isoxaflutole (b).

Figura 2 - Índice de tolerância (TI) de isolados do fungo ectomicorrízico Pisolithus sp. crescidos em meio de cultura MNM sólido adicionado de glyphosate (a) ou isoxaflutole (b).

extremely toxic for isoxaflutole, proposed by the Ministry of Agriculture, Livestock and Food Supply. Therefore, this demonstrates the need for further studies to evaluate the current classification of these herbicides.

The greatest tolerance level of EMF in solid medium than in liquid may be due to agar addition as solidifier agent, which interferes in ion absorption and translocation processes. Meanwhile, they can also represent the best fungus ability to control herbicide ingress into cells, differently of what was observed in liquid medium. This behavior has also been observed in studies that evaluated EMF tolerance to heavy metals in liquid medium (GRAZZIOTTI et al., 2001; GRAZZIOTTI et al., 2003). It is probable that the behavior of herbicide molecules in soil is similar to the observed for solid medium. Thereby, other researches must evaluate herbicide effects on symbiosis formation and effectiveness in their presence.

Stimulaton occurrence, effect absence or growth reduction of different $P$ isolithus sp. isolates in culture medium observed in this research was similar to other studies using other species in medium with addition of 2,4-D and glyphosate (ILOBA, 1978).

Revista Árvore, Viçosa-MG, v.38, n.3, p.461-468, 2014
The lowest toxic effect of isoxaflutole suggests that this herbicide can be used in areas that have been deployed with inoculated seedlings with EMF. Nevertheless, assays under field conditions, in which applications of these products have been frequent, should be conducted to evaluate results in natural reforestation environment because physiological effects on plants can affect mycorrhiza formation.

\section{CONCLUSIONS}

Isolates of ectomycorrhizal fungus Pisolithus sp. differ in tolerance to herbicides, being this result dependent on herbicide type and concentration and culture medium type.

Pt24 was the most tolerant to glyphosate and the UFVJM04 to isoxaflutole. Glyphosate was more toxic to isolates of Pisolithus sp. than isoxaflutole was.

\section{ACKNOWLEDGEMENTS}

We thank the Foundation of Research Support of Minas Gerais State (FAPEMIG) and to the CNPq, for financial support. 


\section{REFERÊNCIAS}

ALLEN, M. F. The ecology of

mycorrhizae. Cambridge: Cambridge University Press, 1991. 184p.

ALVES, J. R.et al. Efeito de inoculante ectomicorrízico produzido por fermentação semisólida no crescimento de Eucalyptus dunnii Maiden. Pesquisa Agropecuária Brasileira, v.36, n.2, p.307-313, 2001.

CAMPOS, D. T. S. et al. Colonização micorrízica em plantios de eucalipto. Revista Árvore, v.35, n.5, p.965-974, 2011.

CULDLIN, P.; MEJSTRIK, V.; SKOUPY, J. Effects of pesticides on ectomycorrhizae of Pinus sylvestris seedlings. Plant and Soil, v.17, n.3, p.353-361, 1983.

ESTOK, D.; FREEDMAN, B.; BOYLE, D. Effects of the herbicides 2,4-D, glyphosate, hexazinone, and triclopyr on the growth of three species of ectomycorrhizal fungi. Bulletin of

Environmental Contamination and Toxicology, v.42, p.835-839, 1989.

FONSECA, A. J. Seleção de isolados de Pisolithus para mudas clonais de eucalipto em viveiro comercial. 2013. 106f. Dissertação (Mestrado em Produção Vegetal) - Universidade Federal dos Vales do Jequitinhonha e Mucuri, Diamantina, 2013.

GRAZZIOTTI, P. H. et al. Efeito de Zn, Cd e Cu no comportamento de fungos ectomicorrízicos em meio de cultura. Revista Brasileira Ciência do Solo, v.25, n.10, p.831-837, 2001.

GRAZZIOTTI, P. H.; SIQUEIRA, J. O.; MOREIRA, F. M. S. Espécies arbóreas e ectomicorrizas em relação ao excesso de metais pesados. In: CERRETA, C. A.; SILVA, L. S.; REICHERT, J. M. Tópicos em ciência do solo. Viçosa, MG: Sociedade Brasileira de Ciência do Solo, 2003. v.5. p.55-105.

ILOBA, C. The influence of 2,4-D on ectomycorrhizal symbiosis in pine and spruce seedlings. European Journal of Forest Pathology, v.8, n.5/6, p.379-383, 1978.
KELLEY, W. D.; SOUTH, D. B. Effects of herbicides on in vitro growth of mycorrhizae of pine (Pinus spp.). Weed Science, v.28, n.5, p.599-602, 1980.

LAKE, D. B. et al. Effect of herbicides on the growth of Pisolithus tinctorius and Scleroderma aurantium in pure culture. In: NORTH AMERICAN CONFERENCE ON MYCORRHIZAE, 5., 1981, Québec. Proceedings... Québec: 1981. p.62.

MARX, D. H.; CORDELL, C. E. The use of specific ectomycorrhizas to improve artificial forestation practices. In: WHIPPS, J. M.; LUMSDEN, R. D. (Ed.). Biotechnology of fungi for improving plant growth. New York: Academic Press, 1989. p.1-25.

MARX, D. H. The influence of ectotrophic mycorrhizal fungi on the resistance of pine roots to pathogenic infections. I. Antagonism of mycorrhizal fungi to root pathogenic fungi and soil bacteria. Phytopathology, v.59, n.2, p.153163, 1969.

BRASIL. Ministério da Agricultura, Pecuária e Abastecimento. Disponível em: <http:// www.agricultura.gov.br/>. Acesso em: 13 mar. 2013.

MOORMAN, T. B. A review of pesticide effects on microorganisms and microbial processes related to soil fertility. Journal of Production Agriculture, v.2, n.1, p.14-23, 1989.

PAULA JR, T. J. et al. Efeito de glifosate e oxyfluorfen sobre Pisolithus tinctorius e sobre a micorrização de raízes de Eucalyptus grandis. Revista Árvore, v.19, n.2, p.241-248, 1995.

RODRIGUES, B. N.; ALMEIDA, F. S. Guia de herbicidas. 6.ed. Londrina: GRAFMARKE, 2011. 695p.

ROSLYCKY, E. B. Glyphosate and the response of the soil microbiota. Soil Biology

Biochemistry, v.14, n.1, p.87-92, 1982.

SILVA, M. A. et al. Formação de ectomicorrizas por monocários e dicários de Pisolithus sp. e interações nutricionais em Eucalyptus grandis. Revista Brasileira Ciência do Solo, v.31, n.5, p.917-929, 2007.

Revista Árvore, Viçosa-MG, v.38, n.3, p.461-468, 2014 
SOUZA, L. A. B.; SILVA FILHO, G. N.; OLIVEIRA, V. L. Eficiência de fungos ectomicorrízicos na absorção de fósforo e na promoção do crescimento de eucalipto. Pesquisa Agropecuária Brasileira, v.39, n.4, p.349-355, 2004.

SOUZA, L. A. et al. New isolates of ectomycorrhizal fungi and the growth of eucalypt. Pesquisa Agropecuária Brasileira, v.43, n.2, p.235-241, 2008.

TOLEDO, R. E. B. et al. Faixas de controle de plantas daninhas e seus reflexos no crescimento de plantas de eucalipto. Science Forum, v.26, n.64, p.78-92, 2003.
TUFFI SANTOS, L. D. et al. Intoxicação de espécies de eucalipto submetidas à deriva do glyphosate. Planta Daninha, v.24, n.2, p.359-364, 2006.

TRAPPE, J. M.; MOLINA, R.; CASTELLANO, M. Reactions of mycorrhizal fungi and mycorrhizal formation to pesticides. Annual Review of Phytopathology, v.22, p.331-359, 1984.

WARDLE, D. A.; PARKINSON, D. Relative importance of the effect of 2,4-D, glyphosate, and environmental variables on the soil microbial biomass. Plant and Soil, v.134, n.2, p.209-219, 1991. 